\title{
Servitization 2.0: The significance of product and service dominant logics for public service organisations
}

\author{
Caroline Ennis (caroline.ennis4d@gmail.com) \\ Westminster Business School, University of Westminster \\ Nicholas Barnett (n.barnett@westminster.ac.uk) \\ Westminster Business School, University of Westminster
}

\begin{abstract}
This conceptual paper explores servitization as significant to public service organisations (PSOs) within which there is a requirement to administer lean and sustainable provision. It specifically appreciates that the digital transformation of services has embraced customer processing machine technologies that facilitate volume growth alongside information sharing; thus, fostering co-operation within collaborative network systems whilst pro-actively operating as elements of the product-service system (PSS). It demonstrates the significance of gooddominant logic (GDL) and service-dominant logic (SDL) perspectives when considering servitization within specific PSOs, and therefore seeks to better understand the strategic and operational realities for the era of Servitization 2.0.
\end{abstract}

Keywords: Servitization 2.0, Service-dominant logic, Public service management

Introduction / purpose

Servitization now enters an era of critical development (Baines, Bigdeli, Bustinza, Shi, Baldwin, \& Ridgway, 2017; Bigdeli, Baines, Bustinza, \& Shi, 2017), having predominantly evolved from the perspective of goods-dominant logic (Smith, Maull, \& Ng, 2014), wherein the emphasis tends to be placed with the original equipment manufacturer (OEM), or equipment provider, within the product-service- system (Spring \& Araujo, 2009). Generally, the implementation of servitization has meant the resultant transformation of product-centric businesses, wherein there is a shifting of the business model logic towards service provision, which has fostered the claim of viability of servitization strategy across the broad range of industries and sectors; when the actual reality is that servitization takes differing paths, and brings about differing trajectories depending on the environment in which it is applied (Turunen \& Finne, 2014). This is pertinent, in that we ultimately seek to understand more deeply the impact of servitization principles within public service organisations, and particularly to explore the critical realities within public transport systems that rely heavily on service equipment (such as escalators) for their customer processing and service quality.

\section{Research methodology/approach}

We attempt to evaluate and progress servitization research for novel and conceptual purposes by exploring the broader realities of its application as we enter the Servitization 2.0 era. We seek to determine from the academic literature the general implications of contextual issues and tensions experienced by PSOs at a point in time when they are rapidly digitally transforming their operational activities, whilst also increasingly operating within interorganizational networks, requiring a more transparent, accountable measurement of their 
performance outcome. Critical arguments are determined from the literature to be able to clarify the more recent characteristics in relation to the organizational and operational strategy as relevant and significant to goods or service logic within PSOs; and the way in which these enable the scope of business benefits to be realized in the fourth industrial revolution. Whilst the broader perspectives of PSOs is the starting point for the general understanding of the impact of digital transformation, with its revised characteristics, we are particularly interested in its impact within public transport systems relying on the servitization of their products and efficient and effective service delivery.

\section{Servitization from the service-dominant perspective}

Public services are evolving and are being transformed into service systems leading to the changing nature of their management towards the new model of networked governance (Osborne, Radnor, \& Nasi, 2012) and accountability (Virtanen, Stenvall, Kinder, \& Hatam, 2018). As such, the associated business models require inter-firm operational capabilities (Spring \& Araujo, 2009) and business logic that addresses the challenges of survival (Osborne, Radnor, Kinder, \& Vidal, 2014). Parnell, Stone, \& Aravopoulou (2018), within their research on the service sectors, determine that in the public sector there is a role that information plays in the business model choice, which is particularly critical if it intends to stay competitive. This is particularly pertinent since much of the servitization of products within the transport system relies on data collection and information sharing within the network of suppliers, to be able to provide efficient and effective service delivery. Ordanini and Parasuraman (2011:3) consider that service innovation operates within a service network involving collaboration and capability and understand the complexity of service operations wherein there is an emphasis on service-dominant logic; but this is not generalizable as it is in the case of a luxury hotel. Newer theories espouse identifying public service-dominant logic as there are flaws emanating from product and manufacturing dominance (Osborne, Radnor, \& Nasi, 2012).

Findings (expected)

Many arguments in the literature demonstrate that it is not necessarily the goods or service element that dominate the business model but that it is more critical to consider the new ecosystem of suppliers, partners and customers. However, where previously integrated solutions were the first generation of servitization, there is now a move, in the second generation of servitization to modular solutions which require competitive capabilities of efficiency and effectiveness (Rajala, Brax, Virtanen, \& Salonen, 2019) and more focus on business information and the associated model of business that this brings about (Parnell, Stone, \& Aravopoulou, 2018).

\section{Theoretical and practical contribution}

It is pertinent to seek to understand how the holistic perspective of the service-dominant ecosystem (Luftenegger et al, 2013) enables collaboration and value and what this business model looks like in specific services operating within the product-service system contexts. In doing so prescriptive research "principally concerned with questions on how the reality should be" (Bigdeli et al. 2017:15) could seek to understand more deeply the value that they bring when cooperating within the business ecosystem and how these apply in relation to productservice-systems in the next servitization era. 


\section{References}

Baines, T., \& Lightfoot, H. W. (2013). Servitization of the manufacturing firm: Exploring the operations practices and technologies that deliver advanced services. International Journal of Operations \& Production Management, 34(1), 2-35.

Baines, T., Bigdeli, A. Z., Bustinza, O. F., Shi, V. G., Baldwin, J., \& Ridgway, K. (2017). Servitization: revisiting the state-of-the-art and research priorities. International Journal of Operations and Production Management, 37(2), 256-278.

Bigdeli, A. Z., Baines, T., Bustinza, O. F., \& Shi, V. G. (2017). Organisational change towards servitization: a theoretical framework. Competitiveness Review: An International Business Journal, 12-39.

Luftenegger, E., Comuzzi, M., \& Grefen, P. (2013). The Service-Dominant Ecosystem: Mapping a Service Dominant Strategy to a Product-Service Ecosystem. PRO-VE International Federation for Information Processing AICT, 408, 22-30.

Ordanini, A., \& Parasuraman, A. (2011). Service Innovation Viewed Through a ServiceDominant Lens: A Conceptual Framework and Empirical Analysis. Journal of Service Research, 14(1), 3-23.

Osborne, S. P., Radnor, Z., \& Nasi, G. (2012). A New Theory for Public Service Management: Toward a (Public) Service-Dominant Approach. America Review of Public Administration, 135158.

Osborne, S. P., Radnor, Z., Kinder, T., \& Vidal, I. (2014). Sustainable public service organisations: A public-service dominant approach. Society and Economy, 36, 313-338. Ostrom, A. L., Parasuraman, A., Bowen, D. E., Patricio, L., \& Voss, C. A. (2015). Service Research Priorities in a Rapidly Changing Context. Journal of Service Research, 18(2), 127159.

Parnell, B., Stone, M., \& Aravopoulou, E. (2018). How leaders manage their business models using information. The Bottom Line, 31(2), 150-167.

Rajala, R., Brax, S. A., Virtanen, A., \& Salonen, A. (2019). The next phase in servitization: transforming integrated solutions into modular solutions. International Journal of Operations \& Production Management, 39(5), 630-657.

Smith, L., Maull, R., \& Ng, I. C. (2014). Servitization and operations management: a service dominant-logic approach. International Journal of Operations and Production Management, 242-269.

Spring, M., \& Araujo, L. (2009). Service, services and products: rethinking operations strategy. International Journal of Operations and Production Management, 29(5), 444-467.

Turunen, T., \& Finne, M. (2014). The organisational environment's impact on the servitization of manufacturers. European Management Journal, 32, 603-615.

Virtanen, P., Stenvall, J., Kinder, T., \& Hatam, O. (2018). Do accountabilities change when public organisations transform to service systems: A new conceptual approach. Financial Accountability \& Management, 34, 166-180. 